\title{
Public and Secret Networks of News: The Declaration of War of the Turks against the Empire in 1683
}

\author{
Stéphane Haffemayer
}

Behind the printed piece of news are concealed different networks, usually invisible. The problem of the newswriter's sources and the networks underlying them is one of the most difficult questions in the study of early modern periodicals. The main question this case study addresses is precisely this relation, between the operation of a network and the making of news. I focus on a single event, namely the announcement of the declaration of war of the Turks against the Empire.

\section{Introduction: Three Networks for the Same Piece of News}

The map of the ordinary news published in the French Gazette in 1683 shows twenty major cities which share and dominate the news market (Figure 35.1); though they are located on key nodes of the network of postal routes, they transmit more or less information depending on the nature and location of events. This is why the network news published in a periodical like the Gazette has to be considered as an active quantity, the evidence for which lies in the case study that reveals adaptations or dysfunctions of the network. This latter is a living structure, with a variable geometry, that changes with the news and with foreign policy priorities. As we can see in the next graph (Figure 35.2), the jolts of current affairs generate a very variable flow, which changes the hierarchical order between the cities.

Vienna was the most prolific city in the 1683 Gazette; week by week, all European newspapers followed the renewed tension between the Turks and the Empire. In this Viennese news item of 1683, the moment of the announcement of the Turkish declaration of war in March allows us to compare three kinds of sources: scribal news, printed news, and diplomatic letters. The same piece of news may be derived from different sources, spread through different networks and serve different strategies of communication.

The printed news, translated in French, appeared in at least two periodicals: 
Provenance of news in the Gazette in 1683

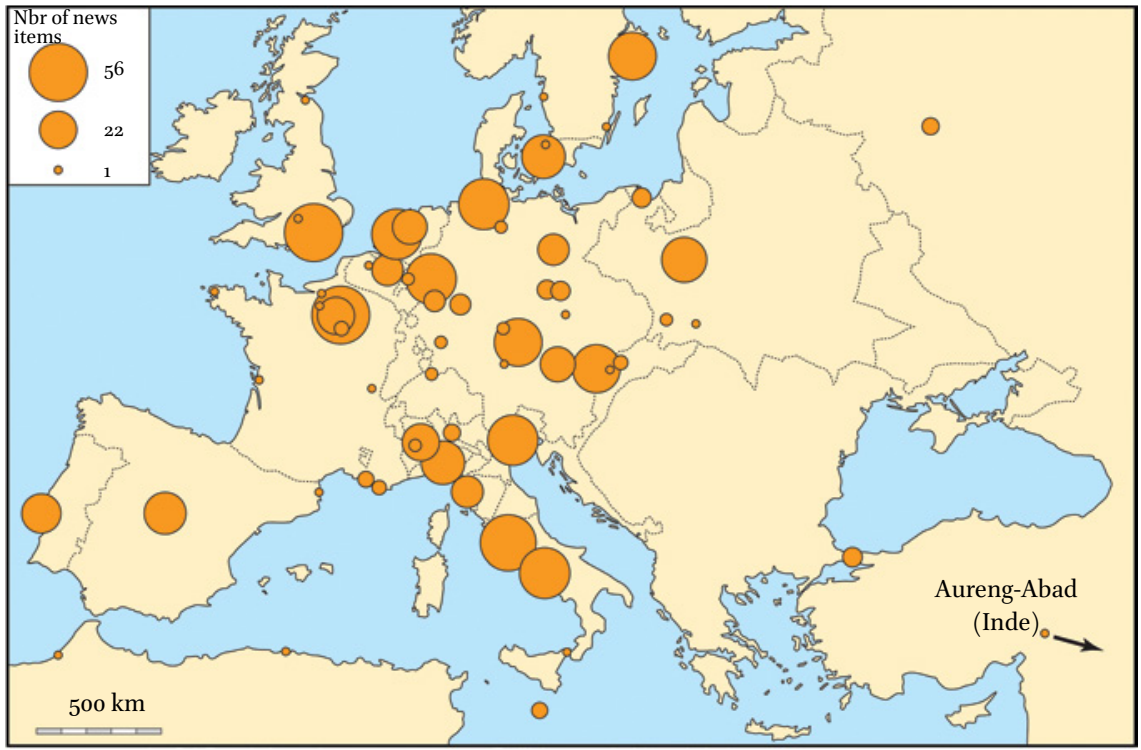

FIGURE 35.1 Information in the Gazette of Paris by city of origin for 1683 (number of news items $)^{1}$

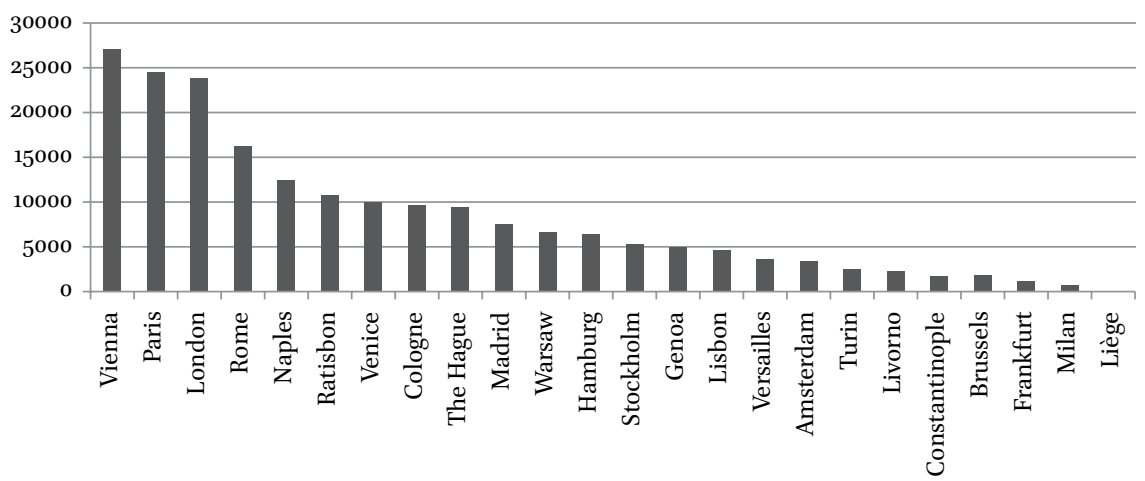

FIGURE 35.2 Volume of news published in the Gazette in 1683 (number of words, by city of origin)

1 The database contains 63 cities providing news in 1683; for an analysis of the electronic instrumentation of the Gazette in 1683, 1685 and 1689, see <www.unicaen.fr/gazette/index .php $>[10 / 5 / 15]$. 
(1) The Gazette, with a piece of news from Vienna, dated ${ }_{15}$ March, published in Paris on 3 April:

Gazette du 3 Avril 1683

De Vienne, le 15 Mars 1683

L'Empereur a reçeu depuis deux ou trois jours, une nouvelle dépesche du Comte Albert Caprara son Envoyé Extraordinaire à la Porte. Elle contient qu'il a eu quelques conférences avec l'Aga des Janissaires: qu'il luy avoit demandé de la part du Grand Seigneur, si on estoit résolu ici de céder à Sa Hautesse les Isles de Schut, de Raab \& de Sérin, avec les Forteresses de Comore, de Raab \& d'une autre place: \& qu'il l'avoit asseuré que ce n'estoit qu'à cette condition qu'on pourroit accorder à Sa Majesté Impériale la prolongation de la Tréve : que le Comte Albert Caprara ayant répondu qu'il n'avoit aucun pouvoir pour accorder des demandes si extraordinaires, l'aga luy avoit repliqué que le Sultan son Masitre estoit assez puissant pour obtenir par les armes tout ce qu'il demandoit : \& qu'aussitost, le Grand Visir avoit fait exposer le signal de la guerre. Les mesmes Lettres portent que les Turcs se préparoient à se mettre en campagne le 18 d'Avril, pour agir en plusieurs endroits en mesme temps : \&, conjointement avec les Troupes du Comte Thékéli, des Princes de Transilvanie, de Moldavie \& de Walachie, se saisir d'abord des Provinces \& des Places frontières : qu'à cette fin, le Grand Visir avoit ordonné à l'Aga des Ianissaries de marcher le 25 de ce mois, vers Belgrade avec l'avantgarde de l'armée Ottomane: \& que le Grand Seigneur \& ce Premier Ministre devoient suivre en personne avec le gros de cette armée, que selon le bruit public, sera de plus de cent cinquante mille hommes. On a seu d'ailleurs, que le Grand Visir faisoit depuis quelque temps, garder si étroitement le Comte Albert Caprara \& le résident de l'Empereur, qu'ils n'avoient pas la liberté de sortir de leurs maisons, \& d'avoir aucune communication avec personne. On a aussi appris que les turcs continüant leurs préparatifs extraordinaires, font encore équiper cent dix bateaux à Belgrade \& à Essec, \& cinquante à Bude. On a sçeu par des lettres de cette dernière place, du 27 Février, que le Bacha y avoit tenu un grand Conseil de guerre avec les plus anciens Officiers des places frontières : \& que tous les Bachas voisins s'y devoient trouver le 15 d'Avril. Le 10 de ce mois, on eut avis de Hongrie, que les Infidelles, au nombre de deux mille avoyent surpris un Quartier de Dragons: qu'ils en avoient tüé quarante \& fait plusieurs prisonniers. Le sieur Hoffman Auditeur Général de guerre, qui estoit allé vers le Comte Thékéli, est revenu depuis huit jours. Il a 
rapporté qu'il n'y avoit aucune apparence que l'Empereur pust rien obtenir de la Porte, par son entremise, ny que Sa Majesté Impériale pust espérer de conclure aucun accommodement avec luy, puis qu'il estoit obligé d'exécuter les ordres qu'il a reçeus du Grand Seigneur. On mande aussi de la Haute Hongrie, que le Comte Thékéli a fait publier qu'il se mettra en campagne le 15 May avec vne puissante armée. Ces nouvelles obligent les Ministres de l'Empereur à redoubler leurs soins pour mettre les chose en état de soûtenir une aussi rude guerre que celle qui nous est déclarée par de si puissans \& si redoutables ennemis. On fait presser autant qu'il est possible la montre des Régimens qui ont ordre de marcher, pour avoir en Hongrie, dans le mois d'Avril, une armée considérable sur pied, en attendant l'arrivée des Troupes auxiliaires que l'empereur a envoyé demander à plusieurs Princes. La reveuë générale des Troupes destinées pour la Hongrie, est toujours fixée au 28 de ce mois. L'Empereur y assistera : \& ensuite, il se determinera sur le chois du lieu où il séjournera pendant la Campagne. Le Comte de Hohenloë se dispose à partir pour se rendre à Nuremberg: où il va de la part de l'empereur, pour assister à l'Assemblée des Estats de Franconie \& du Haut Rhin. Le Sieur Stratman a reçeu ordre de partir incessamment pour se rendre à Ratisbone, avec les nouvelles instructions dont il est chargé. ${ }^{2}$

(From Vienna, 15 March 1683. The Emperor received two or three days ago, a new dispatch from Count Albert Caprara, his Extraordinary Emissary to the Porte. It indicates that he had had consultations with the Aga of the Janissaries; that he had asked, on behalf of the Grand Signior, if he had now decided to cede to His Highness the islands of Schut, Raab and Sérin, as well as the fortresses of Comore, Raab and another place; and that he had declared that only on that condition would he be able to offer His Imperial Majesty a prolongation of the truce: that, Count Albert Caprara having replied that he had no authority to grant such extraordinary demands, the Aga had answered that his Master, the Sultan, was powerful enough to obtain all he demanded by the force of arms; and that the Grand Vizier had immediately displayed the signal for war. The same letters indicate that the Turks were preparing to undertake a campaign on 18 April, in order to attack in several places at once; and, together with the troops of Count Thékeli, the Princes of Transylvania, Moldavia and Wallachia, in order to first seize the Provinces and frontier regions; that, to this end, on the 25th of this month, the Great Vizier had ordered the

2 Bibliothèque nationale de France, Gazette de France, $4^{\circ}$ LC $^{2} .1$ A, microfilm (M 197), 1683. 
Aga of the Janissaries to march towards Belgrade with the vanguard of the Ottoman army; and that the Grand Signior and the Prime Minister were to follow in person, with the main part of this army, which, according to public rumor, will number over 150,00o men. It was learnt, in fact, that the Grand Vizier kept Count Albert Caprara and the Emperor's Resident under such close guard that they were not free to leave their own houses or to communicate with anyone. It has also been learnt that the Turks are continuing their extraordinary preparations, and are equipping 110 ships in Belgrade and Essec, and $5^{0}$ at Buda. We were informed by letters from Buda, dated 17 February, that the Bacha had held a great Council of War there, with the longest standing officers of the frontier regions; and that all the neighboring Bacha should assemble there on 15 April. On the 1oth of this month, we received information from Hungary, that infidels numbering 2,00o had surprised Dragoons' quarters, that they had killed 40 of them and taken several prisoners. Mr Hoffman, the War Auditor General, who had been to see Count Thékeli, returned eight days ago. He reported that there was no indication that the Emperor could obtain anything from the Porte, through his intervention, nor that His Imperial Majesty could hope to conclude any arrangement with him, since he was obliged to execute the orders he had received from the Grand Signior. It is reported from Upper Hungary, that Count Thékeli has announced that he will embark on a campaign on 15 May, with a powerful army. This news obliges the Ministers of the Emperor to redouble their efforts to ensure that everything is made ready to face such a harsh war as that which has been declared on us by such powerful, such formidable enemies. Inspections of the troops who have received marching orders are being speeded up as much as possible, so that, in the month of April, there will be a considerable foot army in Hungary, before the arrival of auxiliary troops that the Emperor has requested several Princes to send. The general inspection of troops to be sent to Hungary is still scheduled for the 28th of this month. The Emperor will be present; then he will decide on the place at which he will stay during the campaign. The Count of Hohenloë is preparing to leave for Nuremberg, where he is going on behalf of the Emperor, to attend the Assembly of the States of Franconia and the Upper Rhine. Mr Stratman has received orders to leave immediately for Ratisbon, with the new instructions he has been given.)

The text explains that the Emperor had received two or three days previously a letter from his ambassador Caprara announcing the failure of the negotiations and the declaration of war. At this time, the privilege of the Gazette was held by 
Eusèbe Renaudot the third; by 'privilege', we mean an exclusive licence, granted him by the King, to print the news for a limited period. ${ }^{3}$ This great-grandchild of the founder of the Gazette was closely linked to the scholars of the Académie Française and to the staff of the foreign ministry, especially the minister himself, Colbert de Croissy. So he benefited from the resources of the diplomatic network, though he had other resources as well, as we will see below.

(2) The Nouvelles extraordinaires de divers endroits, also called the Leiden Gazette, published twice a week. ${ }^{4}$ The information from Vienna is included in the news from Cologne; it is dated 19 march and published in Leiden on 25 March, thus earlier than in Paris. This extract comes from an editorial forgery. But it is almost the same text:

(From Cologne, 19 March. Communications received from Vienna indicate that other letters from the Count of Caprara, dated 24 January, had been received, declaring that finally he had been given an audience with the Aga of the Janissaries, who had told him that his Master the Emperor could have peace with the Grand Signior if he agreed to cede to His Highness the island of Schut, Cziakaturn, and all the region of Raab; and that the Count having replied that he had no authority to agree to that, the Aga had answered that His Highness would try to obtain by the force of his arms what he did not wish to cede by a treaty, and that the next day, the horse's tail had been displayed, which for the Turks is the signal for war, and the signal that troops are on the march; that the Aga had received the order to prepare, and be on the march by 25 March with his troops; and that the Grand Signior and the Grand Vizier were to leave on 1 April and take the road to Griexweissembourg, like him. Besides the 50 ships that the Porte was preparing to use on the Danube, it had ordered the preparation of 100 more at Esegh and Belgrade for the same purpose, and had sent an order to the Cham of Tartary, as well as to the Prince of Transylvania and to the Hospodars of Moldavia and Wallachia, to stand ready to embark on a campaign with their troops as soon as the first command was received. The same thing was confirmed of Offen on 27 February, and it was added that the Vizier had held a great Council of War, which all the old officers of the frontier regions had attended; and that according to the conclusions reached there, the troops on the frontiers were to proceed to Offen on 15 April with all the neighboring Bacha;

3 Gilles Feyel, L'annonce et la nouvelle: la presse d'information en France sous l'Ancien Régime (1630-1788) (Oxford: Oxford University Press, 2000), p. 439.

4 Bibliothèque nationale de France, G 4279. 


\section{De Colognele is Mars.}

L'on écrit de Viene du i i que l'on y aroit receu d'autres lettres duComte de Caprara du 24 Janvier qui donnoit avis, qu'enfin il avoit (fté conduit ì l'audiance du Aga des Janiflaires, qui luy avoit dit que l'Empereur fon Maitre pourroit avoir la paix avec le grand Seigneur s'il vouloit ceder à fa Hautefle l'lile de Schut, Cziakaturn, \& tout le païs de Raab; \& que le Comte luy repondant qu'il n'avoic point d'ordre pour cela, l'Aga luy avoit repliqué que faHauteffe tacheroit d'avoir par la force de fes armes ce qu'on ne vouloit pas luy ceder par un traité, \& que le lendemain l'on y avoit arboré la queuë de cheval, qui eft parmi les Turqs le Signal de la guerre \& de la marche des rroupes; que l'Aga avoit eu ordre de fe preparer à fe mettre en marche dés le 25 Mars avec fes troupes; \& que le grand Seigneur \& le premier Vizir devoient partir le I Avril \& prendre la routc de Griexweiffembourg, comme luy. Outre les so barques que la Polte faifoit apprefter pour s'cn fervir fur le Danube, elle avoit ordonnéd'en preparer cncore une centaine à Efegh \& à Belgrade dans le même deffein, \& énvoyé ordre au Cham de Tartarie, deméme qu'au Prince de Trantilvanie \& aux Hofpodars de Moldavie \& de Valachic de fe tenir prets à fe mettre en campagne avec leurs troupes au premier commandemene qui leur en feroit fait. On confirmoit la même chofe d'Offen du 27 Fevrier; \& l'on ajoutoit que le Vizir y avoit tenu grand Confeil de guerre, où. tous les vieux Officiers des frontieres avoient affifté; \& que felon les conclufions qui s'y eftoient prifes, ies troupes qui eftoient fur les froutieres. devoient fe rendre a Offen le I 5 Avril avec tous les Baffas voifins: \& l'on avoit avis de Hongrie que le Teckeli, conformement ì l'ordire qu'il en avoit receu, fe tenoit preft avec autant de troupes, d'armes \& de munitions, \& une aufi forte artillerie que fes forces pouvoient luy permettre, \& pretendoit fe mettre en campagne i la mi-May pour le pluftard avec une armée de soono Hommes. Le Sieur Hofman, Aide Major General, y eftoit de retour de Caffovie, ou il avoit efté quelque temps prés du Teckeli. Le Comte de Lamberg en devoir partir bientoft avec de nouvellss inftructions pour la Cour de Son Alrefle Electorale de Brandebourg. Et l'on y ayoit encore nyis de
FIGURE 35.3

Nouvelles Extraordinaires de divers endroits, 25 March 1683 
and the opinion was expressed in Hungary that Teckeli, in accordance with the order he had received, was standing ready with as many troops, arms and ammunition and as strong an artillery as his forces could provide, and he planned to embark on a campaign mid-May at the latest, with an army of 50,00o men. Mr Hofman, the Deputy Major-General, had returned from Cassovia, where he had been by the side of Teckeli for some time. The Count of Lamberg was to leave there soon with new instructions for the Court of His Electoral Highness of Brandenburgh.)

The scribal news sources called 'News from Vienna' dated 11 and 14 March are among the diplomatic correspondence between France and the Empire. ${ }^{5}$ We find them throughout the diplomatic correspondence for 1683 . These consisted essentially of public news of the Imperial Court, of the town, of the Turkish advance, of the negotiations with the Hungarians, and so on.

\section{(News from Vienna \\ 11 March 1683}

Mr Pratman was about to leave here in order to return to Ratisbonne, but his return was delayed for important reasons. He must stay here for some time, all the more so because he is one of the major contenders for the post of Chancellor, but it is very doubtful whether His Imperial Majesty will prefer a foreigner to subjects capable of taking on this responsibility.

Negotiations are continuing with the Extraordinary Envoy of Brandenburgh.

His Imperial Majesty has decided to recall the Count of Altheim, his Ambassador in Sweden, because the alliance with the Swedish crown is definitely established and determined. We are informed here that Sweden has 24,000 men throughout the Empire and will send a corps of another five or six thousand Swedes.

Three days ago, letters were received here from the Internuncio Caprara datelined Adrianople.)

In fact, Vienna was at the time the most important centre for the transmission of information from the east to the west. Letters from the eastern front were deciphered, and commented on by the members of the Council of State: this inner circle seems to be at the origin of much of the oral information. On precisely

5 Ministère des Affaires Etrangères, France: Correspondance politique, Autriche, no. 55, microfilm no. P 16761, fos. 96-99. 


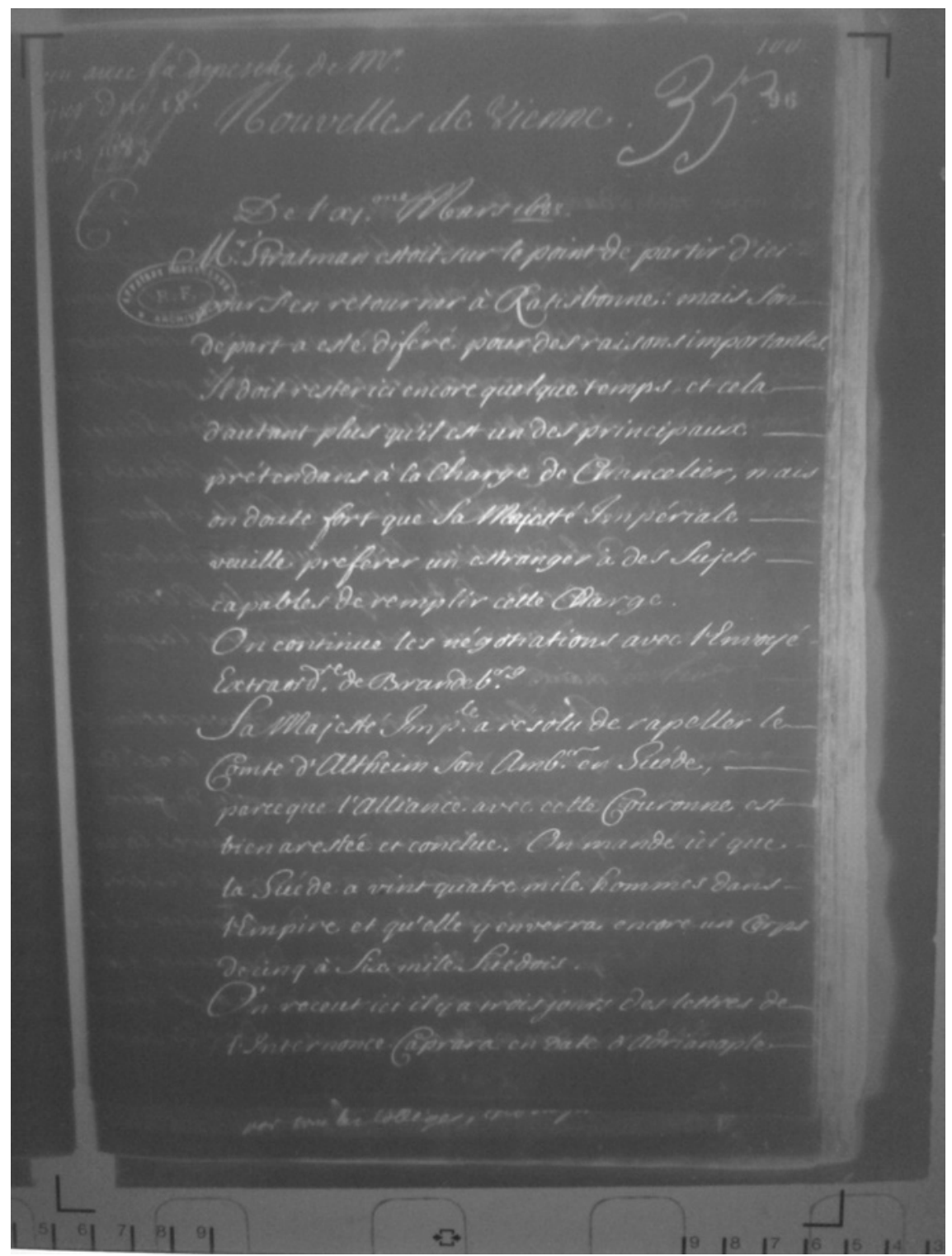

FIGURE 35.4 Microfilm of 'Nouvelles de Vienne' (diplomatic newsletter, 9-14 March 1683)

that subject, in a letter to the king, the French ambassador remarked that the councillors were incapable of holding their tongues about state affairs, and that they were responsible for many indiscretions about matters which were normally the province of the arcana imperii. An argument in favour of the diffusion from this inner circle is that the news from Vienna rarely gave the same date for 
the arrival of the letter announcing the war. Small differences in the details may indicate an oral source. Copyists never had access to the original of this kind of official letter; thus the source of the information was partly the indiscretion of the councillors who used to communicate news to the copyists.

The news items were sent alongside the diplomatic letters of the French ambassador at Ratisbon, Louis de Verjus, who translated the German news and sent it to Versailles. ${ }^{6}$ We do not know where these pieces of news came from but it is not impossible that they came from the avvisi which circulated between the Empire and Italy.

Local items of news from Vienna could also be extracted from the two periodicals printed in Vienna: the Italian Il Corriere ordinario, published twice a week since 1671, of which some copies are extant in the UK National Archives; and the Viennese Ordinari Reichs-Zeitung. ${ }^{7}$ They also constituted a possible source for the scribal information which was sent beyond Vienna.

Within the letter 'News from Vienna', we can clearly distinguish two different sections. The first is the news sent by the Palatine resident; the second is sent by the resident of Brandenburg. Significantly, the identity of these correspondents is enciphered. Both were France's allies and belonged to the diplomatic circle which acted for the French ambassador in Vienna, sometimes in the role of intermediary, sometimes in the role of informer. It confirms the importance of the role of Resident agents in the spread of the news.

Probably this parallel network of information had been established at Renaudot's own request: he and Verjus belonged to the same set of scholars of the Académie Française. The prevailing problem for a gazetteer was the shortage of information: in a letter in 1680, Renaudot explained that he needed help from his friends in obtaining news, especially from Spain and Portugal. ${ }^{8}$ In this case, the network of the gazetteer lay somewhere between an official and a personal network.

The third network in action was the diplomatic one, as exemplified in a letter dated 11 March 1683, almost entirely in cipher:

(A message arrives from Caprara, coming via Raguze, who is sending Saponara everywhere, with the position of Internuncio at the Porte, and sent by the Porte. I will assure him that Saponara is gone, but I very much

6 Ministère des Affaires Etrangères, France: Correspondance politique, Autriche, no. 55, microfilm no. P 16761, fo. 8.

7 TNA: State Papers 118, 'Gazettes, edicts and pamphlets printed in the Holy Roman Empire [1588-1791]'

8 Gilles Feyel, L'annonce et la nouvelle, p. $45^{\circ}$. 


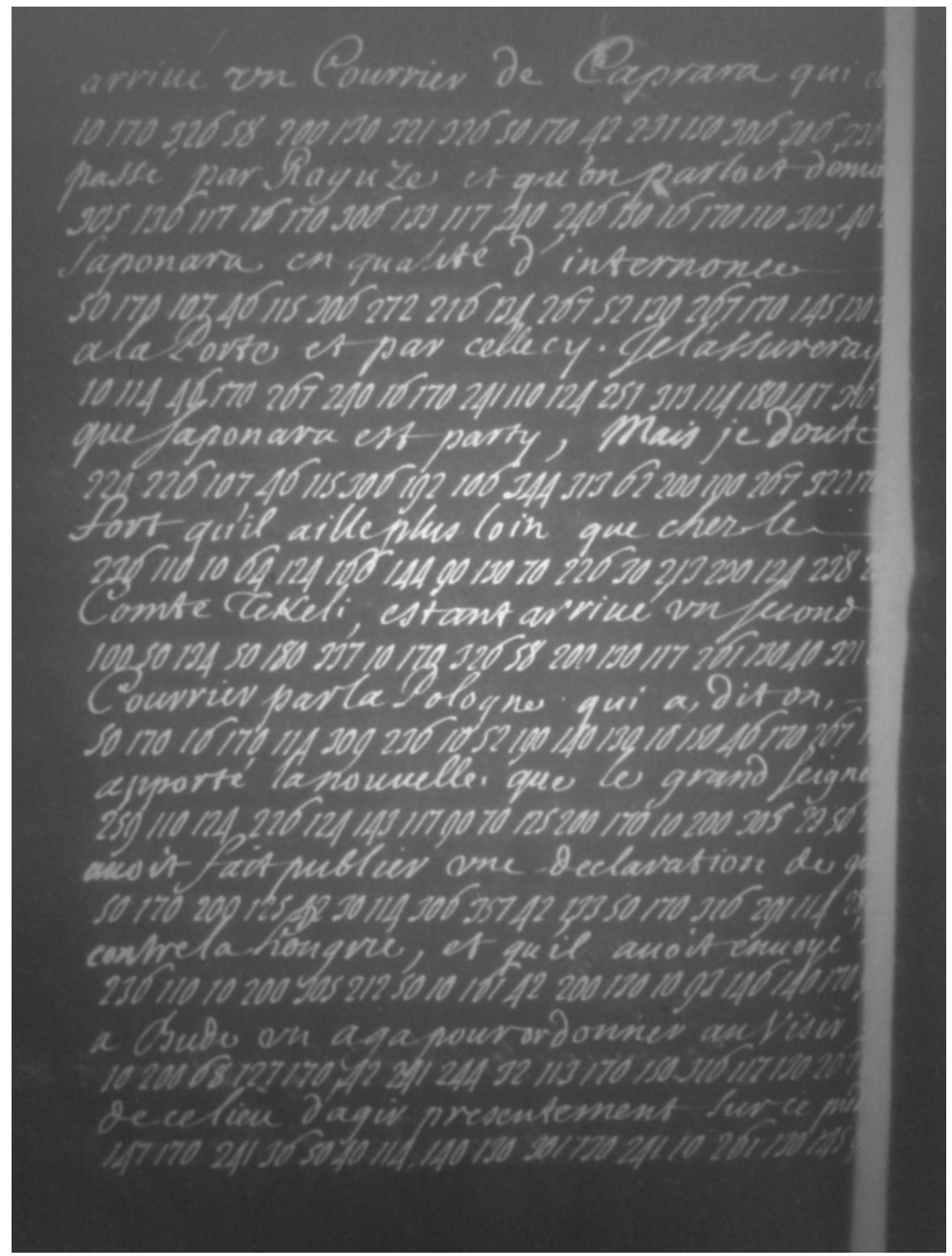

FI GURE 35.5 Manuscript of the Marquis de Sébeville's ciphered letter of 11 March 1683

doubt that he will go further than Count Tekeli, since a second message has arrived via Poland, which is said to have brought the news that the Grand Signior had published a declaration of war against Hungary, and that he had sent an Aga to Bude to order the Vizier there to immediately act in this matter.) 
The French ambassador in Vienna, the marquis of Sébeville, wrote twice a week, at each ordinary post. He used two different postal routes, one to the north, running essentially straight and following the Danube to Cologne (by way of Vienna, Lintz, Ratisbon, Nuremberg, Würzburg, and Frankfurt); the other to the south, via Salzburg, Munich, and Augsburg. He always tried to use the faster road. But whatever route he chose for it, the French correspondence was carefully spied upon, as will appear below.

\section{What is the Relation between Handwritten and Printed News?}

Logically, the most prolific information came from the scribal news; conversely, the Gazette conveyed more carefully controlled and selected information (Figure 35.6).

The second point to expand upon is the transformation of scribal news into printed news. Viennese news from scribal sources was printed in Paris and Leiden with minor transformations and adaptations.

\section{(I) From Scribal News to Printed News}

The announcement that the Turks were going to war against the Empire was published on 25 March in Leiden and on 3 April in Paris. Both publications

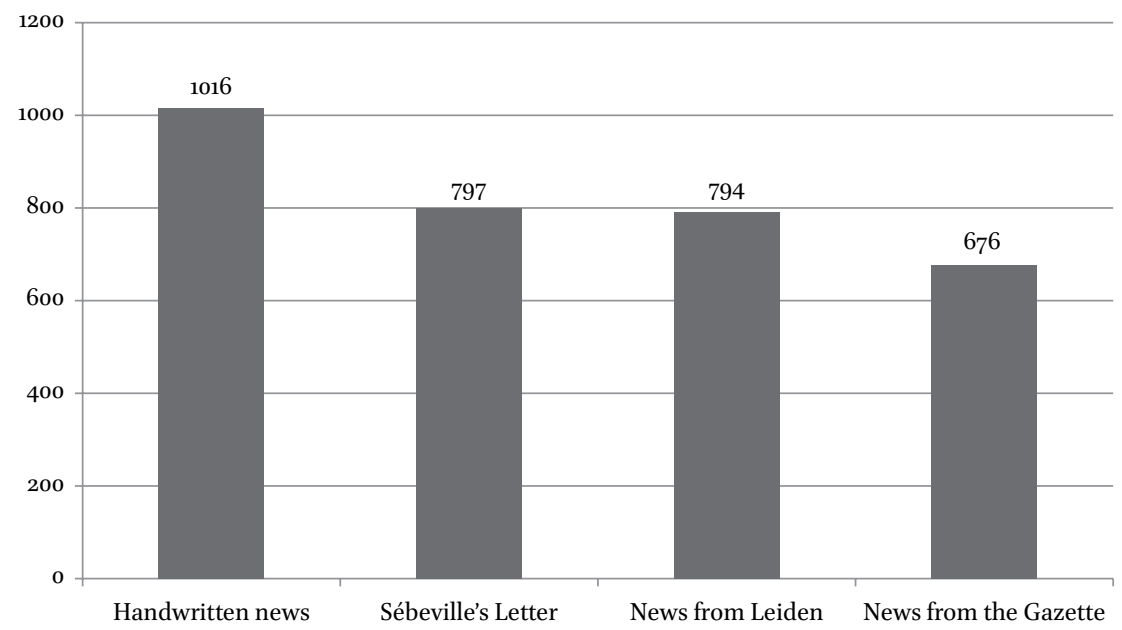

FIGURE 35.6 Volume (number of words in the different sources described above, 11-14 March 1683) 
relied on the same source, in this case the scribal news from Vienna sent to Ratisbon and Cologne. This is one of the exceptional cases in which it is possible to compare the printed news with its source. As we can see below, the narrative's construction is totally identical in the three extracts:

Nouvelles de Vienne. De l'XIe mars 1683. On receut ici il y a trois jours des lettres de l'Internonce Caprara en date d'Adrianople (sic) du $29^{\mathrm{e}}$ Janvier, d'où il mande, qu'estant arivé en ce lieu là, l'Aga des Janissaires l'avoit envoyé querir et luy avoit demandé si l'Empereur son maistre vouloit consentir aux propositions faites de la part de Sa Hautesse et luy ceder l'Isle de Schut, la Czia Kathura et toute la Lobaw, et qu'ayant allégué làdessus le defaut d'Instruction, l'Aga luy avoit declaré par ordre de sa Hautesse, que la Porte poursuivroit ses prétentions l'espée à la main. On sait que depuis cette conversation la queue de cheval a esté exposée le $25^{\mathrm{e}}$ du mesme mois ...9

(News from Vienna, 11 March 1683. Letters were received here three days ago, from the Internuncio Caprara, dated Adrianople (sic), 29 January, which informed us that when he had arrived there, the Aga of the Janissaries had sent for him and had asked him if his Master, the Emperor, was willing to agree to the proposals made by His Highness and cede to him the island of Schut, Czia Kathura and all Lobaw, and when he underlined that he had no orders on this matter, the Aga had declared, by order of His Highness, that the Porte would pursue its claims, sword in hand. We know that after that conversation, the horse's tail was displayed on the $25^{\text {th }}$ of the same month.)

De Cologne, le 19 Mars. L'on écrit de Viene du 11 que l'on y avoit receu d'autres lettres du Comte de Caprara du 24 janvier qui donnoit avis, qu'enfin il avoit esté conduit à l'audiance du Aga des Janissaires, qui luy avoit dit que l'Empereur son Maitre pourroit avoir la paix avec le grand Seigneur s'il vouloit ceder à sa Hautesse l'Isle de Schut, Cziakaturn, \& tout le païs de Raab ; \& que le Comte luy repondant qu'il n'avoit point d'ordre pour cela, l'Aga luy avoit repliqué que sa Hautesse tacheroit d'avoir par la force de ses armes ce qu'on ne vouloit pas luy ceder par un traité, \& que le lendemain l'on y avoit arboré la queuë de

9 Archives diplomatiques, Ministère des Affaires Etrangères, France: Correspondance politique, Autriche, no. 55, microfilm no. P 16761, fos. 96-9. 
cheval, qui est parmi les Turqs le Signal de la guerre \& de la marche des troupes ...10

(From Cologne, 19 March. Communications received from Vienna indicate that other letters from the Count of Caprara, dated 24 January, had been received, declaring that finally he had been given an audience with the Aga of the Janissaries, who had told him that his Master the Emperor could have peace with the Grand Signior if he agreed to cede to His Highness the island of Schut, Cziakaturn, and all the region of Raab; and that the Count having replied that he had no authority to agree to that, the Aga had answered that His Highness would try to obtain by the force of his arms what he did not wish to cede by a treaty, and that the next day, the horse's tail had been displayed, which for the Turks is the signal for war, and the signal that troops are on the march ...)

De Vienne, le 15 Mars 1683. L'Empereur a reçeu depuis deux ou trois jours, une nouvelle dépesche du Comte Albert Caprara son Envoyé Extraordinaire à la Porte. Elle contient qu'il a eu quelques conférences avec l'Aga des Ianissaires : qu'il luy avoit demandé de la part du Grand Seigneur, si on estoit résolu ici de céder à Sa Hautesse les Isles de Schut, de Raab et de Sérin, avec les Forteresses de Comorre, de Raab et d'vne autre place: et qu'il l'avoit asseuré que ce n'estoit quà cette condition qu'on pourroit accorder à Sa Majesté Impériale la prolongation de la Tréve : que le Comte Albert Caprara ayant répondu qu'il n'avoit aucun pouvoir pour accorder des demandes si extraordinaires, l'Aga luy avoit repliqué que le Sultan son Maistre estoit assez puissant pour obtenir par les armes tout ce qu'il demandoit: et qu'aussitost, le Grand Visir avoit fait exposer le signal de la guerre ...11

(From Vienna, 15 March 1683. The Emperor received two or three days ago, a new dispatch from Count Albert Caprara, his Extraordinary Emissary at the Porte. It indicates that he had had consultations with the Aga of the Janissaries; that he had asked, on behalf of the Grand Signior, if he had now decided to cede to His Highness the islands of Schut, Raab and Sérin, as well as the fortresses of Comorre, Raab and another place; and that he had declared that only on that condition would he be able to 
offer His Imperial Majesty a prolongation of the truce: that, Count Albert Caprara having replied that he had no authority to grant such extraordinary demands, the Aga had answered that his Master, the Sultan, was powerful enough to obtain all he demanded by the force of arms; and that the Grand Vizier had immediately displayed the signal for war.)

Undoubtedly, these texts come from the same source: the manuscript news sent from Vienna and published in two rival periodicals, at Leiden and Paris.

Nevertheless, it was not a simple and slavish copy: the expression varies with the differences of translation and the style of the gazetteer. In the Parisian case, the writer composed his text from a mix of the different sources: the information provided by the residents brings a touch of originality that we do not find in the other reports. The diversity of the sources makes the rewriting necessary and easier. Above all, the writer organised his information according to the priorities of French foreign policy and adapted the information to the culture of his readers.

\section{(i)}

\section{Adaptation to Geographical Knowledge}

Each periodical used a specific register of toponyms: this geographical acculturation was necessary to perceive the strategic stakes on the national and European scales. This is why the place names given in the original reports from Vienna were differently rendered in Paris and in Leiden. For example, 'Czia Kathura' in the scribal news became 'Cziakaturn' in Leiden's news but disappeared from the Gazette of Paris, where the names of the fortresses were commonly used, such as Comorn, and Raab.

\section{(ii) Adaptation to Foreign Policy}

The purpose of the reports from Vienna in the Gazette was to attract the public's attention to the eastern front in Europe, while the main focus of French policy was on the western front, through offensive actions in peacetime. It is well known that Louis XIV aimed to facilitate Turkish attacks against the Empire's border to avoid an imperial military reaction in the West. Since April 1682, French diplomacy had assured the Turks of France's benevolent neutrality in the event of war against the Empire. Thus the information presented in the Gazette was intended to fashion opinion on the war through very detailed accounts of the failure of the negotiations with the Turks. The diplomatic correspondence was occasionally used thanks to letters from French residents in Transylvania and the Ottoman Empire. From time to time, the reliability of the intelligence of the diplomatic networks brought an additional precision to public information, as I shall show in my next section. 
To return to the Gazette, the insistence on the Turkish threat aimed to demonstrate the failure of Imperial foreign policy which wasted time in negotiations at Ratisbon, with a particular concern to restrain French expansionism, and failed to concentrate all its efforts on the mobilisation of troops against the traditional enemy of Christendom. So in this case, news had a plasticity, manifested by its literary construction in the service of foreign policy; this is why the 1683 report consisted of a news item rewritten with some judicious cuts made.

For example, the Gazette said absolutely nothing precise about the conduct of the Turkish armies: yet the French ambassador wrote that the heads of Christian prisoners had been cut off and exposed on Neuhausel's ramparts, painting a terrifying picture. But the Gazette, which usually relished sensational information, kept silent about this 'signal of war' in order not to demonise a useful diplomatic ally. In the same way, it said nothing about the reversal of alliances when Hanover, Sweden, Brandenburg, Poland, Bavaria, etc., decided to join the Imperial cause (which was reported in close detail in the London Gazette).

In brief, the Gazette used different and complementary networks of information to support an overall diplomatic strategy. The French were said not to be very aware of the realities of the East, and Dutch periodicals regarded as the most efficient in the transmission of news from east to west. Using the example of the Gazette of Leiden, we cannot assert that the Dutch network was more impressive, or more efficient, than the French network of the Gazette, but rather that it was a combination of public, diplomatic and secret networks which completed each other.

Curiously, the letter from the ambassador dated 11 March seems to be the least informed about Caprara's Imperial letter. It only evoked the rumour of a letter arrived by way of Poland and a declaration of war of the Turks against Hungary. In his following letter of 14 March, he only wrote very laconically that 'the last letter of Caprara confirms the war completely'. Why so little detail?

The main reason is that in this case, the diplomatic network was much less effective than the network of manuscript news. From his arrival, the letters of the ambassador were very closely watched, intentionally slowed down, spied on, deciphered and diverted by the Imperial cabinet.

The covert war between France and the Empire was above all an information war. The main task of the French ambassador in Vienna was to organise an 
efficient structure of information. He was clearly a kind of spy whose mission defined the contents of his correspondence very exactly: he was to organise and maintain a flow of political information that should "penetrate into all the imperial resolutions" including diplomatic and military news, the progress of negotiations with the Turks and the Hungarians, the mobilisation and movement of troops, the number of soldiers, names of commanders, whether soldiers' wages were paid or not, affected quarters, and so on.

The French network of information in this era was an espionage network; from 1675 , France had a permanent resident in Transylvania, who corresponded secretly with France by way of Poland and supported the Hungarian revolt against the Emperor. So France was relatively well informed about the regional realities, which allowed the Gazette to give very precisely the dates of the mobilisation of the Turks and Hungarian-details which we do not find in the handwritten news from Vienna.

The official instructions given to the ambassador insisted on the quality of his information, because that information would determine decision-making: the King expected in particular that his ambassador report word for word all that he heard at Court. Diplomatic correspondence was consequently an almost daily affair, ciphered as fast as it was written. It aimed at giving a personalised answer to the instructions received: consequently, letters were almost entirely coded. The espionage activities of the ambassador had direct consequences: namely relative isolation within the court and very tight controls placed on his correspondence.

At the end of June 1683, Louis XIV complained about the fact that the letters of his ambassador in Vienna were always delayed, and that consequently the information which he received was frequently anticipated by the public news. To try to accelerate the transmission of diplomatic information, the King asked his ambassador to use the post of the merchants of Strasbourg or Cologne. But the ambassador apologetically explained that in the context of the war, there was an Imperial ban on the Viennese merchants receiving the letters of foreign Ministers - especially the French. He added that the particular letters which he succeeded in entrusting to a merchant of Strasbourg were often stopped and opened.

The study of the timings of the post confirms that the delivery times for the diplomatic letters were effectively very elastic (Figure 35.7), yet the same information appeared with great regularity in the Gazette.

In fact, the Imperial government tried to prevent communication between France and the Hungarian rebels, as well as between France and the Turks. The objective of this control of their communications was to bring to light the secret policy of France, to drag Poland away from the French alliance and to 


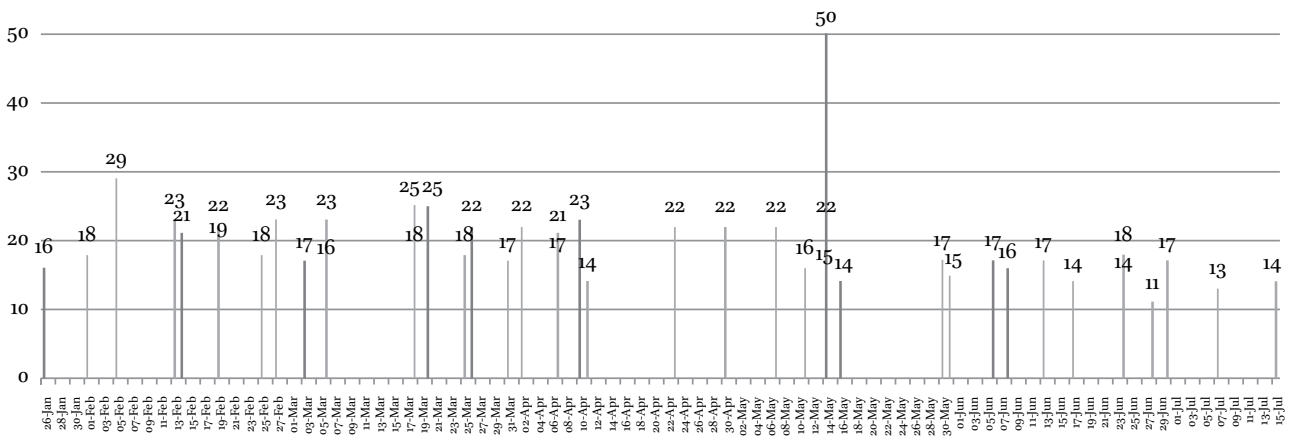

FIGURE 35.7 Delivery time of the diplomatic letters between Vienna and Versailles in 1683

obtain Polish military support against the Turks. In December 1682, letters between the French ambassador in Poland and the French resident in Transylvania were intercepted, proving French support for the rebel Hungarians. ${ }^{12}$ The French ambassador in Poland had been publicly unmasked in front of the king of Poland by the Imperial resident. The letters were then published in the Italian gazette, probably Il Corriere ordinario, which was printed in Vienna (naturally Louis XIV asked his ambassador to send him a copy). The incident brought to light the existence of secret information networks and the workings of French foreign policy, which fascinated the readers.

At the end of April 1683, the ambassador learned that his letters were not only intercepted but also deciphered. ${ }^{13} \mathrm{He}$ had the evidence of this in July 1683 and immediately sent a courier to inform the King about it: the courier arrived in five days (much faster than usual). ${ }^{14}$ In fact, the French cipher had been revealed to the Venetian ambassador in Poland by a sub-clerk of the French secretariat. We do not have the name of the traitor but we know the reason of the denunciation: the Prince of Schwarzemburg revealed the information in the hope of being spared Louis XIV's annexationist policy. Consequently, during the six months which preceded the siege of Vienna, the Imperial government

12 Ministère des Affaires Etrangères, France: Correspondance politique, Autriche, no. 54, microfilm no. P 16760 , fos. 13v-14r, 105v-106r.

13 Ministère des Affaires Etrangères, Correspondance politique, Autriche, no. 54, microfilm no. $\mathrm{P} 16760$, fos. 312-13.

14 Idem., fo. 404. 
was well informed about France's strategic intentions. This explains the isolation which surrounded the post of the French ambassador in Vienna and the importance of the existence of parallel networks.

To conclude, this case study on Viennese information in 1683 teaches us several things about the secret and public networks through which it flowed:

i. First, in the early modern period, the authorities were actively involved in the process of information distribution, and followed the process of democratisation of access to information. The networks of public and private information were not clearly differentiated, however. The published information was a careful elaboration, elements of which issued from very different networks.

ii. Secondly, the journalist was no mere scribe: he wove together his information from diverse sources, recomposing a text for a national readership that possessed a common culture and common points of reference. In this case, the cultural connections with the orientations of the foreign policy were very strong.

iii. Thirdly, even in the service of the formation of national opinion, newspapers constitute a remarkable tool for acquiring knowledge of European current events, even for the sovereigns themselves, because they were sometimes more efficient and reliable than diplomatic. Subtle relations of competition and complementarity exist between the official diplomatic networks and the less formal ones exploited by the gazetteers. 